\title{
Het historia, svala museer ${ }^{1}$
}

\author{
Katherine Hauptman* \& Fredrik SVAnberg*
}

Title: Hot history, cool museums

Abstract: There is an ongoing tension between the modern museum concept, rooted in deep traditions within modernity, and the developments within the humanities over the last 30 years. The later movement, and not the least within museology, normally strives towards a more socially engaging museum, working with contemporary social and cultural issues. The article describes and discusses a number of research and development projects dealing with involvement, public archaeology, gender, diversity and the uses of history that have been undertaken by the authors at the Swedish History Museum in Stockholm during the last six years. Some points covered in the article are that dividing lines, or opposing positions, are often not between institutions but between different kinds of activities within institutions, and that institutions eager to work with a broader scope and to engage socially will also have to deal with more debates and criticism as well as the potential for threats against staff. Museums have the power to re-imagine and to have an effect on public culture, but that is a process not without complexity.

Key words: Hot topics, public archaeology, museums and gender, museums and diversity.

\author{
VAR GOD VIDRÖR EJ \\ En dag ska jag skapa ett museum \\ där man får röra vid \\ alla konstverk: \\ lystna fingrar kan \\ sjunka in i skulpturer, smeka \\ skrovliga dukar, följa \\ handstilen \\ i manuskript \\ former konturer \\ kan svälla i en hand \\ där man kan lukta på
}
konst om man vill
slå armarna
runt den, rulla den
över golvet, bita
i konst om man får lust
sparka på ett föremål som väcker ilska, slita sönder det som provocerar och slicka på de verk som utlöser glädje
Konst som förblir intakt kommer att plockas bort Shailja Patel, ur Migritude 
Symboliskt sätter Shailja Patels dikt fingret på en grundläggande motsättning mellan ett samhällsengagerande museum där man får röra vid, lukta på och bita i de utställda sakerna och ett museum där föremålen ska bevaras helt oförändrade, vilket gör att de blir meningslösa och kan plockas bort.

$\AA$ ena sidan står vi här med den moderna sortens museer, med en drygt 150-årig historia som institutionstyp. Museer som på många sätt konstruerats som hållbarhetsstrukturer. Museer som grundats på sin kategorisering och klassificering av världen och människorna och som med auktoritet och autenticitet från sina samlingar, traditioner och ämnesexperter befäster kategorimönster, kulturella gränsdragningar och etablerade normer. Museer som platser för inlärning av traditioner. Där man inte får röra och där konstverket och världen ska behållas oförändrade.

$\AA$ andra sidan finns en generell utveckling inom kulturvetenskaperna mot ämnesbreddning och nya perspektiv, samt den drygt 20 år gamla så kallade nya museologin som vill skapa ett mer progressivt nytt museum som kan vara en del av samhällets utveckling. Ett museum som arbetar med sociala och kulturella samtidsfrågor, som kan utveckla eller bryta normer och där man får röra symboler och konstverk. Både bokstavligt genom att delta i museiprocesser och i djupare mening genom att revidera gränser och nytolka verkens betydelse och därmed värdehierarkierna för objekt, människor, berättelser. Ett museum där historien kan skrivas på nytt och där man vågar arbeta med det svåra och det politiska.

Denna motsättning mellan museets karakteristiska historiska form och nya idéer och arbetssätt kan inte göras svart och vit. Gamla

museer såg ändå olika ut och de kan förändras och börja arbeta på nya sätt. Nya museer kan å sin sida snabbt bli konservativa och låsta för förändring. Vår erfarenhet - efter att under snart 10 år med Historiska museet som bas ha arbetat på den svenska kulturhistoriska museiscenen med olika slags utvecklingsprojekt med utgångspunkt i delaktighet, mångfald och genusperspektiv - är att spänningen mellan museernas klassiska sätt att tänka och fungera och viljan att omsätta nya kunskaper och perspektiv i nya sätt att arbeta är fortsatt relevant och betydelsefull. Men skiljelinjen går inte nödvändigtvis mellan olika slags museer, utan snarare mellan olika delar av verksamheten inom samma institution.

Frågan om hur museerna ska vara ställs på sin spets i en samtida situation där kulturella och sociala samhällsfrågor rörande identitet, nation, mångfald, traditioner och sexualitet är heta och till stor del politiskt polariserade i hela Norden. Liknande diskussioner om museers samhällsroll märks i många andra länder (Silverman 2010). Brittiska Museums Association lanserade nyligen kampanjen Museums Change Lives där museer uppmanas att ta sitt ansvar för att främja social förändring.

Museums change people's lives. They enrich the lives of individuals, contribute to strong and resilient communities, and help create a fair and just society. Museums in turn are immensely enriched by the skills and creativity of their public. (Museums Change Lives 2013.)

Den klassiska gamla museiformen har en samhällspolitisk laddning, liksom försöken att arbeta på nya sätt. Museets otvetydiga roll som formare av identiteter, normer och kollektiv samhällskultur (t.ex. Message 2006, HooperGreenhill 2007) lämnar den svala museikroppen ingen ro undan den heta historien. 


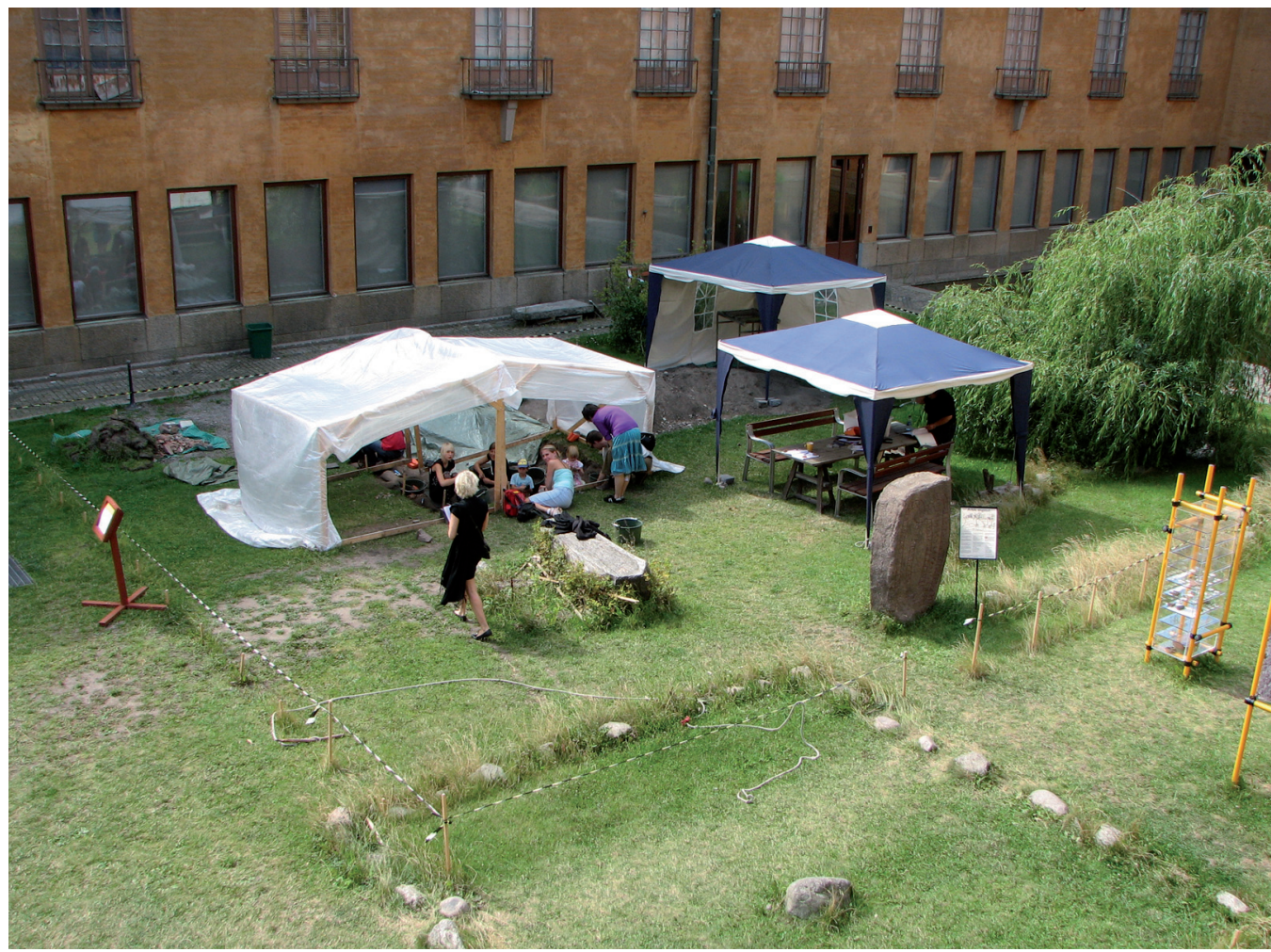

Fig. 1. Arkeologisk utgrävning på Historiska museets stora innergård 2008. Undersökningen togs bland annat som utgangspunkt för att diskutera museets egen historia. Foto: Erik Rothman, Historiska museet.

VILJAN

Historiska museet har sedan flera år i utställningar, utvecklingsprojekt och pedagogiska program arbetat med historia och arkeologi på sätt som utgår från historiens funktioner för människor och i samhället. För att engagera människor har det varit viktigt att fokusera hur de kan göras delaktiga. Med den utgångspunkten har vi utvecklat olika forsknings- och utvecklingsprojekt inom temat Publik arkeologi från 2006 och framåt (Svanberg \& Hauptman Wahlgren 2007, Gullström et al. 2013).
Målen har varit att öka den professionella arkeologins kontaktytor, att göra fler människor delaktiga och kunniga samt att de publika relationerna i större utsträckning än tidigare ska präglas av samskapande och reflektion. Det ska märkas i praktiken att allas rätt till kulturarvet är en demokratifråga.

För att uppnå detta måste kommunikationen skifta från ett slags pedagogisk empirism, där arkeologiska resultat först skapas av experterna och sedan sprids, till ett arbetssätt som mer handlar om att dela den utforskande upptäcktsresan med andra intressenter och med 
150 publiken. Det innebär även en öppenhet för att tillvarata kunskaper och erfarenheter hos människor utanför den egna gruppen. Genom publika utgrävningar och insamlande utställningar har vi prövat olika koncept och det stod snart klart att de största hindren för att integrera dessa projekt i den ordinarie museiverksamheten var själva museets organisation, interna ansvarsfördelning och samlingspraktiker. Projektens upplägg synliggjorde oreflekterade rutiner, inte minst $\mathrm{i}$ frågor om vilka historier som är intressanta och om föremålens värdehierarki (Svanberg \& Hauptman Wahlgren 2007, Hauptman Wahlgren \& Svanberg 2008, Svanberg 2008, Hauptman Wahlgren 2010).

Som en fortsättning av arbetet med publik arkeologi, fast med en tydligare inriktning mot historiebruk deltog Historiska museet i ett samarbete inom ramen för Svenska Institutets satsning Creative Force för att utveckla museernas samhällsroll i västra Balkan. Bland annat arrangerades konferensen Why Museums and to Whom - Museum as Forum and Actor vid Museum of Yugoslav History i Belgrad, som också resulterade i publikationen The Museum as Forum and Actor (Svanberg 2010). Samarbetet bestod förutom av konferensen även av ömsesidiga studiebesök och kortare perioder av arbetspraktik mellan museianställda i Stockholm och Serbien och skedde i samverkan med svenska ambassaden i Belgrad, kulturorganisationen C31 för barns rättigheter samt Museum of Yugoslav History. Hela omfattningen av de kultur- och utvecklingsprojekt som initierades och/eller samordnades under Helene Larssons period som svenskt kulturråd i Belgrad finns beskriven i boken This is Not a Report (Larsson 2012).

Erfarenheterna från dessa projekt gav inblickar i sammanhang och situationer där hi- storia i praktiken är på liv och död, vilket tillförde helt nya dimensioner till frågorna om demokratiskt historiebruk. Inte minst är Centre for Democracy and Reconciliation in Southeast Europes (CDRSEE) arbete med alternativa läroböcker om sydöstra Europas historia, The Joint History Project ett viktigt och inspirerande projekt för att hantera historia som något gemensamt, men inte nödvändigtvis unisont, för olika grupper. Läroböckerna är ett samarbete mellan lärare, historiker, översättare och redaktörer från alla de sydösteuropeiska länderna och syftar till att motverka att historia används i konflikter mellan länder och grupper (Koulouri 2009, se även presentation hos Šebek 2010).

\section{INSIKTER}

Medvetenhet om historiebrukets anatomi och kraft är en förutsättning för att historia ska kunna fungera som demokratiskt verktyg. Detta är tydligt i många europeiska länder där nationerna har ombildats och förändrats många gånger under ganska kort tid. Efter Sovjetunionens fall har nationalistiska perspektiv, och inte minst nationalistisk historieskrivning, fătt förnyad aktualitet för de stater som ska återuppfinna sig själva. Svenska museer har mycket att lära från dessa sammanhag då mötet med deras verkligheter också avslöjar och ifrågasätter svenska normstrukturer.

$\mathrm{Vi}$ anser att en upprepad växelverkan mellan praktiskt prövande FoU-projekt och teoretisk reflektion över historiebruk är en bra väg till att långsiktigt göra museerna mer samhällsengagerade. Med sin breda verksamhet har museiorganisationerna särskilt goda förutsättningar att vara miljöer för interaktiv forskning. Här finns många gånger personal som 
kompetensmässigt spänner över flera fält från det traditionellt forskningsanknutna och antikvariska till lärande och marknadsföring. Det är en mångdisciplinär miljö. Tillgång till museet som "testlaboratorium" för olika typer av undersökningar ska inte heller underskattas, även om det förstås ställer speciella krav att göra kritiska studier av en verksamhet man är del av. Studier visar dock att de anställda i kultursektorn socialt kan betraktas som en relativt enhetlig grupp som delar liknande uppsättningar kulturella erfarenheter (t.ex. Feiler 2010, Edström \& Hyltén-Cavallius 2011). En befogad fråga är därför hur stor acceptansen egentligen är för oliktänkande och viljan att ta in nya perspektiv.

Museer kan fungera som effektiva lärmiljöer. Men de behöver designas för att stödja människors historiemedvetande $\mathrm{i}$ framtidens samhälle snarare än att reproducera modernismens föreställningar om det förgångna. Det innebär både att synliggöra den mångfald av grupper och identiteter som finns i historien och att släppa fram fler röster och perspektiv i samtalet - gärna samtidigt. Ungdomar med mångkulturell identitet tycks utan problem kunna identifiera sig med multipla historier och hybrida identiteter, många av dem kan ledigt kombinera värden och kunskaper från olika kulturer. Men omvärlden, t.ex. skolan, läroböckerna och museerna, kategoriserar genomgående migrationshistoria i vi- och domtermer, något som trots andra ambitioner motverkar synen på svenskhet som något dynamiskt och föränderligt över tid (Lozic 2010). Invandringen till Sverige under de senaste 40 åren domineras av flykting- och anhöriginvandring (Boguslaw 2012). Många av de nya svenskarna har flytt från katastrofer, svält, förföljelse eller till och med folkmord. De har våldsamma eller i alla fall svåra upple- velser med sig bagaget. Bilden av att "svenska" erfarenheter präglas av fred, jämlikhet och neutralitet börjar skeva. Allt fler i Sverige känner att det fattas något $\mathrm{i}$ historieskrivningen.

\section{HANDLINGAR}

Som en fortsättning på arbetet med publik arkeologi växte FoU-projektet Det medierade museet fram under 2008 och drevs under de följande åren. Grundtankarna var att fortsätta arbetet med delaktighet enligt publik arkeologi-modellen, med bland annat publika utgrävningar. Men nu tillkom dels fokus på att arbeta med historisk arkeologi, dels ett samarbete med Kungl. Tekniska Högskolan och deras forskning om videomediering för kommunikation på distans. Vi använde lämningarna av en viktig och publikt engagerande modernhistorisk händelse, Stockholmsutställningen 1897 på Djurgården, i syfte att vrida och vända på diskrepansen mellan officiella minneskulturer och personliga berättelser och drivkrafter. Flera hundra människor engagerades i publika utgrävningar, där vi också kunde påvisa bevarade lämningar från 1897. Mellan utgrävningsplatsen på Djurgården och Historiska museet etablerades ett medierat "fönster" för realtidskommunikation. Besökaren på museet kunde se utgrävningen och diskutera med arkeologerna och de andra deltagarna. Besökaren på Djurgården kunde delta i undersökningen samt diskutera med museibesökarna. I anslutning till de publika aktiviteterna utforskades 1897-utställningens materiella kulturarv och föremål samlades in (Gullström et al. 2013). Här uppstod också situationer där besökare spontant delgav arkeologerna sina ärvda minnen och själva tog initiativ till att guida varandra runt platsen. 


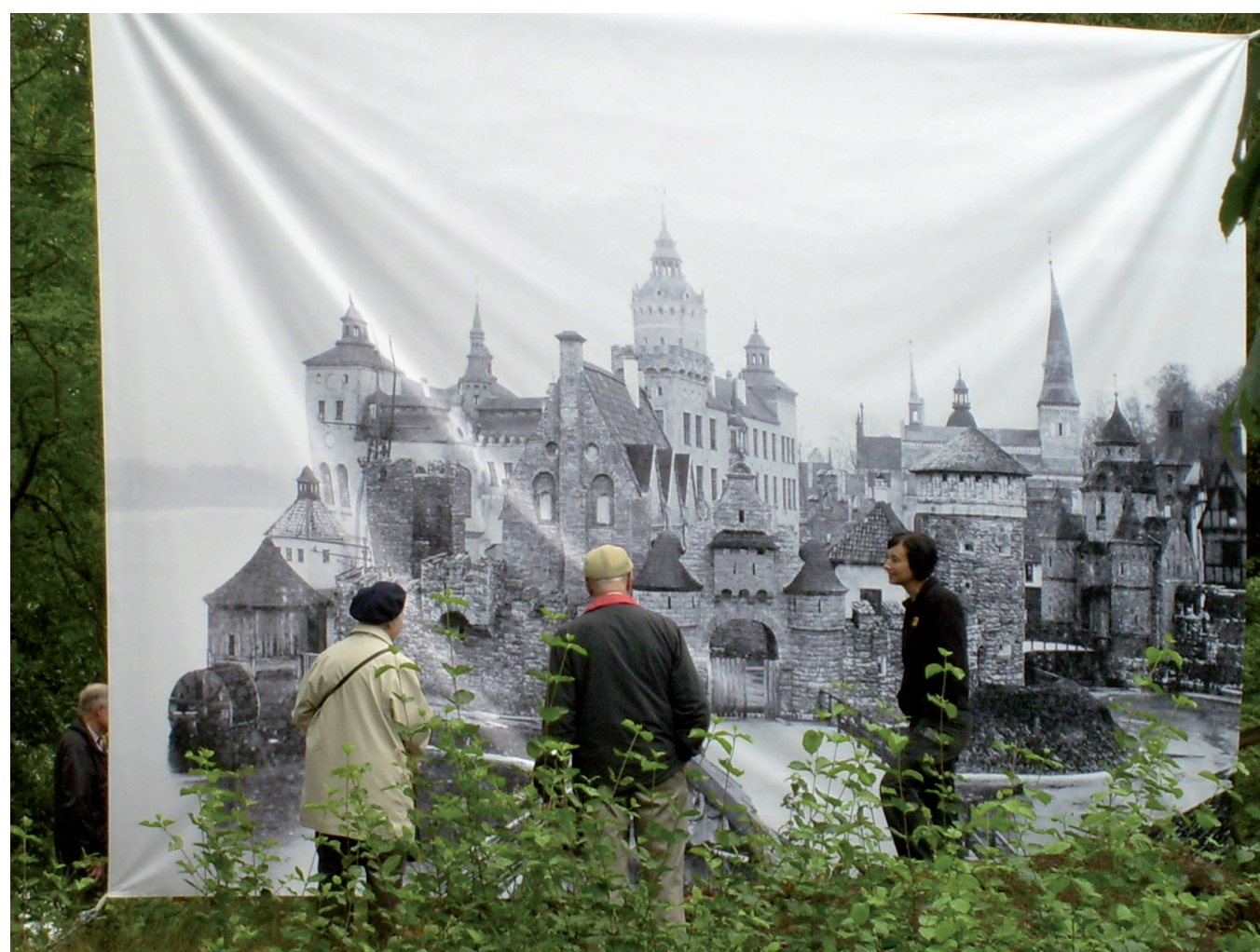

Fig. 2. Förstorat fotografi från Stockholmsutställningen 1897 monterat vid utgräuningsytan på Djurgården 2009. Katherine Hauptman berättar för besökare på platsen. Foto: Fredrik Svanberg, Historiska museet.

Utvecklingen av mångfalds- och genusperspektiv i kulturarvs- och museiverksamheten har på olika sätt varit återkommande inslag i de redan nämna projekten, även om det övergripande paraplyet formulerades som publik delaktighet. Men de senaste tre åren har genus och mångfald explicit blivit huvudfokus för en rad större utvecklingsprojekt. Statens historiska museer ${ }^{2}$ fick 2011 regeringsuppdraget Jämställd representation i utställningar och samlingar, vilket vi valde att uttolka som metodutveckling av genus- och hbtq-perspektiv i museernas verksamhet. Jämus-projektet, som det kom att kallas, bestod av en rad olika delsatsningar som utgick från de behov som formulerades av deltagarna i en hearing i maj 2011 (beskriven i Fernstål 2011). Sammantaget arbetade vi med tre teman: samlingar, utställningar och kunskapslyft. En serie seminarier med starka workshop-inslag engagerade många museianställda från hela landet. Parallellt genomförde Jämus i samarbete med Riksutställningar och fackförbundet DIK utbildningen Leda mångfalt för museichefer. Ytterligare seminarier har hållits vid Riksförbundet Sveriges museers vårmöten 2012 och 2013. 
För att utveckla metoder för genusintegrering i utställningar gjordes en genomgång av utställningen Vikingar på Historiska museet. Elever från gymnasieskolan Rytmus analyserade med normkritiska perspektiv hur människor var framställda och utifrån deras reflektioner genomfördes flera förändringar av bilder, föremålsexponering och texter i utställningen. Jämus följde också produktionen av utställningen Jag är Armfelt på Livrustkammaren i syfte att utarbeta en checklista för att inkludera genusperspektiv vid nyproduktion av utställningar. Metodutvecklingen för samlingar har koncentrerats på hur digitala resurser kan användas för att stödja genuskategorisering av föremål i samlingssystemen eller med hjälp av olika internettjänster såsom flickr, youtube, facebook m.m. Jämusprojektet har också stöttat den fortsatta utvecklingen av Unstraight Museums webbsatsning, ${ }^{3}$ arrangerat workshops och deltagit i panelsamtal i samband med att vandringsutställningen Article One visades på National Historical Museum i Tirana, Albanien, ${ }^{4}$ samt finansierat tryckning av antologin Att störa homogenitet (se nedan). Projektet går i skrivande stund in i en fortsättningsfas med syfte att sprida resultat och arbetssätt även utomlands (Fernstål 2011, Uppdrag jämställda museer 2013).

Ett spår som trots våra intentioner inte rymdes helt inom arbetet med Jämus var den komplexa frågan om mångfaldsutveckling av museernas digitala samlande. Därför är syftet med ett nytt FoU-projekt, Polysemantiskt digitalt samlande, som drivits sedan 2012, att utvärdera och undersöka dels vilka möjligheter som idag finns för arbete med mångfaldsfrågor inom museernas digitala databassystem, dels att skapa nya goda exempel på hur ett utvecklat sådant arbete kan se ut (Fernstål et al., in print).

\section{KONFRONTATIONER}

När museernas verksamhet blir mer samhällsengagerad och tydligare flätas in i frågor om människosyn, mänskliga rättigheter och den pluralistiska samtiden ökar inte bara de "officiella”, gängse kulturdebatterna och kritikyttringarna. I takt med att dialogen blir mer intensiv genom användningen av sociala medier och när öppenheten $\mathrm{i}$ institutionernas arbete blir större tydliggörs och accentueras också konfliktlinjer i olika heta kulturfrågor som löper långt utanför själva musei- och kultursektorn. Konkret innebär detta att institutioner och individer som vill stå för och arbeta med frågor som rör mångfald och människosyn idag kommer att möta olika former av debatt, kritik och även trakasserier i sammanhang utanför den traditionella kultursektorns ramar.

Offentliga personer som bland annat politiker, journalister, samhällsdebattörer och elitidrottare i Sverige upplever en ökande mängd hatreaktioner och hot i sin vardag. De teman som provocerar mest är mångfalds- och genusperspektiv, det vill säga de värdegrunder som många kulturinstitutioner säger sig vilja främja. Eftersom den antifeministiska och rasistiska retoriken är sammanflätad blir också kvinnor särskilt utsatta. Fram till nyligen har museerna varit ganska förskonade från sådana yttringar, men det håller på att förändras.

En rad fall av näthat mot museer i samband med genus- och mångfaldsarbete är kända från de senaste åren. Det finns också exempel på direkt rasistiskt och sexistiskt bemötande mot personal, samt några fall av hot. Hur dessa yttringar ska värderas och vilken påverkan de har på institutionerna och personalen är okänt eftersom studier av hur detta samhällsklimat påverkar museer och kulturarvsar- 
154 bete saknas. Intoleranta strömningar i samhället märks samtidigt i flera länder (jfr t.ex. Bjurwald 2011, Bauman 2012, Linton 2012, Bauman \& Donskis 2013). Men det är oklart hur rasistiska och antifeministiska manifestationer med anknytning till kulturarvet i Sverige ska analyseras i förhållande till motsvarande problematik i andra europeiska länder.

Museerna är generellt ganska tysta i frågor om kränkningar, men 2010 bildades nätverket Federation of International Human Rights Museums. Diskussioner om mänskliga rättheter och hur museer arbetar med svåra teman såsom rasism, homofobi, sexism, slaveri, terror och rövade kulturföremål förekommer också i akademiska publikationer (t.ex. Cameron \& Kelly 2010, Lehrer, Milton \& Patterson 2011, Levin 2010, Dickey, el Azhar \& Lewis 2013). Samtidigt finns en kritik av att museerna inte gör upp med dessa frågor i grunden, liksom att de teoretiska resonemangen om inkludering av mångfald inte tycks avspegla sig i praktiken, i rättvisefrågor och i rekrytering av personal inom kultursektorn (t.ex. Feiler 2010, Edström \& Hyltén-Cavallius 2011, Small 2011, Sandell \& Nightingale 2012). Teorierna om människors ursprung och jakten på kulturell enhetlighet som drivkrafter till historieintresse är fortfarande starkt företrädda inte bara i rasistiska grupperingar utan också i många museers historieförmedling (t.ex. Anderson 1993, Eriksen 1999, Eriksen \& Sörheim 2006, Motturi 2007).

Det är ingen tvekan om att det är viktigt för museerna att arbeta emot olika former av intolerans och här behövs mer kunskap, breddning och fördjupade samarbeten mellan olika slags organisationer. Under 2012 samarbetade Jämus-projektet och flera av Historiska museets forskare på olika sätt med det av Örebro länsmuseum, Upplandsmuseet och Region- museet Skåne koordinerade paraplyprojektet Norm, nation och kultur. Bland annat deltog Historiska museet i konferensserien Att störa homogenitet och $\mathrm{i}$ antologin med samma namn (Furumark 2013). Som en fortsättning har forskningsprojektet Bortom homogeniteten inletts under 2012, fortfarande inom paraplyet Norm, nation och kultur och med forskare från Historiska museet och Mångkulturellt centrum i Botkyrka.

\section{VÄGVAL}

Varje tid uppfattas i någon mån som ny, med förutsättningar som skiljer sig från det som varit. Det är en av anledningarna till att det sällan verkar gå att överföra gamla lärdomar till nya sammanhang. Medvetenheten om hur forntidsromantik, folkstereotyper och historieklichéer samspelar med nationalism och främlingsfientlighet har funnits åtminstone sedan 1940-talet. Parallellt med museernas nationsbyggande funktion finns en växande önskan hos stora delar av den svenska museipersonalen att problematisera den glorifierande enhetshistorien. I texthäftet till utställningen Viking - forntidsdröm och verklighet på Historiska museet berättades så tidigt som 1972 hur bilden av vikingen skapades av 1800-talets överklass (Lundström 1972). Historiska museet fick 1996 ett regeringsuppdrag om att utarbeta ett handlingsprogram mot främlingsfientlighet och rasism. Handlingsprogrammet fokuserade de statliga kunskapsinstitutionernas ansvar för att upplysa om sakförhållanden och historiska perspektiv samt att starta diskussioner. Redan där beskrevs en hårdnande tidsanda som $\mathrm{i}$ allt högre grad exkluderade människor och som fortfarande kan kännas igen från dagens debatter (Kunskap som kraft 1997, Bydén 1998). 
Under 2000-talet har det skett en kunskapsteoretisk förskjutning inom forskningen, från uppfattningen att expertens kumulativa kunskapsuppbyggnad leder till förändring, till en mer diversifierad syn på förändringsprocesser där det blir viktigt att inkludera människors subjektiva erfarenheter. Museernas verksamhet har förstås också förändrats i praktiken t.ex. när det gäller berättarstrukturer, utställningsgestaltning och besökarinteraktion (jfr t.ex. Simon 2010). Men i grunden kvarstår de problem som fanns på 1930-40-talen, på 1970-talet och på 1990-talet med att kulturarvet kan användas som främlingsfientliga redskap. Svårigheterna tycks ligga i att kulturarvet traditionellt väcker mer intresse hos krafter som vill renodla och exkludera människor från svenskhet än hos dem som är aktivister för människors lika värde och det mångfaldiga samhället.

Det nyligen avslutade stora, europeiska Eunamus-projektet ${ }^{5}$ har under flera år undersökt de nationella museernas historia och funktion i Europa. Projektet har visat hur det nationella museet är en europeisk uppfinning för att definiera och stabilisera kunskap och nationell identitet. De nationella museerna konstruerades en gång för att bygga murar runt gemenskaper och fungera som ett slags "kulturella rustkammare" som definierade både "vi" och "de andra". Men forskarna inom Eunamus menar också att det är just detta slags äldre nationella funktion, och den auktoritet som investerats i museerna, som idag också gör dem användbara för nya slags kulturella projekt för att till exempel överkomma motsättningar eller för att etablera nya sociala och kulturella strukturer för framtiden. Museerna har "the power to re-imagine" (Aronsson \& Knell 2012).

Nya publikorienterade projekt om svenskhet och historia med fokus på att släppa fram fler röster från människor utanför museisektorn är redan igång på Historiska museet. Bland annat genomfördes under våren 2013 det pedagogiska pilotprojektet Gränslöst tillsammans med SFI-skolorna (svenska för invandrare) Hermods och SIFA (Stockholms intensivsvenska för akademiker). Eleverna från två klasser skrev personliga texter om historiska föremål och nu finns 35 nya berättelser att läsa i utställningen Sveriges historia. Samtidigt startar museet ett experimentellt samarbete med Art Lab Gnesta ${ }^{6}$ i projektet Contamination of Evidence - att ärva kultur i vår tid, som handlar om hur identitetsfrågor kan utforskas i mötet mellan konst och kulturarv, genom artefakter och av konstnärer. Vår ambition är att det ska lägga grunden till ett större publikprojekt, som under de närmaste åren omfattar både utställningar och andra programaktiviteter på temat svenskhet, identiteter och kulturarv på Historiska museet.

De klassiskt svala museerna har makt att göra nytt och forma kollektiva kulturer, att ge sig in i samtidens hetta och välja nya vägar snarare än att reproducera det gamla. Museer och historia ska beröra. Men vem bestämmer vad som ska smekas och vad som ska slitas sönder? Här pågår en ständig brottning mellan olika ideologier och värdesystem, ibland högljudd, ibland lågintensiv. Endast en sak är klar: de artefakter ingen bryr sig om att krama, slicka på eller sparka kommer med tiden att försvinna.

\section{NOTER}

1. Artikeln bygger på reflektioner och erfarenheter utifrån en rad forsknings- och utvecklingsprojekt och utgör därför inte en enskild projektpresentation.

2. Myndigheten där Historiska museet ingår. 
156 3. www.unstraight.org (hämtad oktober 2013)

4. http://www.aleancalgbt.org/art/28-programi-i-art1-online (hämtad oktober 2013)

5. www.eunamus.eu (hämtad oktober 2013)

6. www.artlabgnesta.se (hämtad oktober 2013)

\section{LITTERATUR}

Anderson, Benedict 1993. Den föreställda gemenskapen: reflexioner kring nationalismens ursprung och spridning. Göteborg: Daidalos.

Aronsson, Peter \& Knell, Simon (red.) 2012. National Museums Making Histories in a Diverse Europe. Linköping: Linköpings universitet. http://liu.divaportal.org/smash/record.jsf?searchId=2\&pid=diva 2:573632 (hämtad 12 oktober 2013)

Bauman, Zygmunt 2012. Collateral Damage: social ojämlikhet $i$ en global tidsålder. Göteborg: Daidalos.

Bauman, Zygmunt \& Donskis, Leonidas 2013. Moral Blindness: the Loss of Sensitivity in Liquid Modernity. Cambridge: Polity.

Bjurwald, Lisa 2011. Europas skam: rasister på frammarsch. Stockholm: Natur \& Kultur.

Boguslaw, Julia 2012. Svensk invandringspolitik under 500 år: 1512-2012. Lund: Studentlitteratur.

Bydén, Ylva 1998. Arbetet mot främlingsfientlighet och rasism vid landets kulturarvsinstitutioner: en rapport. Stockholm: Statens historiska museum.

Cameron, Fiona \& Kelly, Lynda (red.) 2010. Hot Topics, Public Culture, Museums. Newcastle upon Tyne: Cambridge Scholar.

Dickey, Jennifer W, el Azhar, Samir \& Lewis, Catherine M. (red.) 2013. Museums in a Global Context. National Identity, International Understanding. Washington, DC: The AAM Press.

Edström, Nina \& Hyltén-Cavallius, Charlotte 2011. Osmos: inkluderingsprocesser $i$ kulturlivet. Tumba: Mångkulturellt centrum.

Eriksen, Thomas Hylland 1999. Kulturterrorismen: en uppgörelse med tanken om kulturell renhet. Nora: Nya Doxa.
Eriksen, Thomas Hylland \& Sörheim, Torunn Arntsen 2006. Kulturforskjeller i praksis: perspektiver på det flerkulturelle Norge. Oslo: Gyldendal Akademisk.

Feiler, Yael 2010. Transnationell kultur i marginalen, ett vitalt fenomen i motvind: rapport frän ett kartläggningsprojekt utfört av Mångkulturellt centrum med stöd av Statens kulturråd. Tumba: Mångkulturellt centrum.

Fernstål, Lotta 2011. Genusperspektiv i museer. En omvärldsbevakning. Stockholm: Statens historiska museer.

Fernstål, Lotta, Kolker, Li \& Svanberg, Fredrik, in print. Polysemantiskt digitalt museisamlande. Stockholm: Historiska museet.

Furumark, Anna (red.) 2013. Att störa homogenitet. Lund: Nordic Academic Press.

Gullström, Charlie, Handberg, Leif, Hauptman, Katherine \& Svanberg, Fredrik 2013. Det medierade museet. Moderna kulturarvsprocesser och medierad tillgänglighet. I Holmström, Marie (red.). Mångvetenskapliga möten för ett breddat kulturmiljöarbete. Riksantikvarieämbetets FoU-verksambet 2006-2010/11. Stockholm: Riksantikvarieämbetet, 121-134.

Hauptman Wahlgren, Katherine 2010. Future memories in the rear-view mirror. I Svanberg, Fredrik (red.). The Museum as Forum and Actor. Stockholm: The Museum of National Antiquities, 77-94.

Hauptman Wahlgren, Katherine \& Svanberg, Fredrik 2008. Public archaeology as a renewer of the Historical Museum. Public Archaeology 8, 241-258.

Hooper-Greenhill, Eilean 2007. Museums and Education. London \& New York: Routledge.

Koulouri, Christina (seriered.) 2009. Workbook 1-4. Teaching Modern Southeast European History. Alternative Educational Material. Thessaloniki: Centre for Democracy and Reconciliation in Southeast Europe. 
Kunskap som kraft: [handlingsprogram för hur museerna med sitt arbete kan motverka främlingsfientlighet och rasism]. Stockholm: Fritzes 1997.

Larsson, Helene (red.) 2012. This is Not a Report: Cultural Exchange Sweden/Serbia 2009-2012 = Ovo nije izves?taj: kulturna razmena S?vedska/Srbija 2009-2012. Belgrade: Embassy of Sweden in Belgrade.

Lehrer, Erica T., Milton, Cynthia E. \& Patterson, Monica (red.) 2011. Curating Difficult Knowledge: Violent Pasts in Public Places. Houndmills, Basingstoke, Hampshire: Palgrave Macmillan.

Levin, Amy K. (red.) 2010. Gender, Sexuality, and Museums: a Routledge Reader. Milton Park, Abingdon, Oxon: Routledge.

Linton, Magnus 2012. De hatade: om radikalhögerns måltavlor. Stockholm: Atlas.

Lozic, Vanja 2010. I historiekanons skugga: historieämne och identifikationsformering i 2000talets mångkulturella sambälle. Lund: Lunds universitet.

Lundström, Inga 1972. Viking. Forntidsdröm och verklighet. Utställning 25.5-10.91972.

Stockholm: Statens historiska museum.

Message, Kylie 2006. New Museums and the Making of Culture. Oxford: Berg.

Motturi, Aleksander 2007. Etnotism: en essä om mangkultur, tystnad och begäret efter mening. Göteborg: Glänta.

Museums Change Lives. The MA's Vision for the Impact of Museums, 2013.

http://www.museumsassociation.org/download?i $\mathrm{d}=1001738$ (hämtad 12 oktober 2013)

Patel, Shailja 2012. Migritude. Lund: Celanders.

Sandell, Richard \& Nightingale, Eithne (red.) 2012. Museums, Equality and Social Justice. London: Routledge.

Šebek, Nenad 2010. How Turkish is your coffee? The SEE Joint History Project. I Svanberg,
Fredrik (red.) The Museum as Forum and Actor.

Stockholm: The Museum of National

Antiquities, 115-124.

Silverman, Lois H. 2010. The Social Work of Museums. London: Routledge.

Simon, Nina 2010. The Participatory Museum. Santa Cruz, CA: Museum 2.0.

Small, Stephen 2011. Slavery, colonialism and museums representations in Great Britain. Old and new circuits of migration. Human Architecture: Journal of the Sociology of SelfKnowledge 9(4):117-127.

Svanberg, Fredrik 2008. Arkeologisk utgrävning av Statens historiska museum. I Burström, Mats (red.). Samtidsarkeologi - varför gräva i det nära föflutna? Rapport frän en session vid konferensen IX Nordic TAG i Arhus 2007. Huddinge:

Södertörns högskola, 87-96.

Svanberg, Fredrik (red.) 2010. The Museum as Forum and Actor. Stockholm: The Museum of National Antiquities.

Svanberg, Fredrik \& Hauptman Wahlgren, Katherine 2007. Publik arkeologi. Stockholm: Historiska museet.

Uppdrag jämställda museer. Rapport om regeringsuppdraget att ta fram underlag och utveckla metoder... Stockholm: Statens historiska museer 2013.

* Katherine Hauptman, projektledare och FoU-ansvarig för kommunikation och publik katherine.hauptman@historiska.se

* Fredrik Svanberg, forskningschef fredrik.svanberg@historiska.se

Historiska museet

Box 5428

SE-114 84 Stockholm, Sverige 